\title{
Autophagy, Prion Infection and their Mutual Interactions
}

\author{
Andreas Heiseke ${ }^{\#}$, Yasmine Aguib\# \\ and Hermann M. Schatzl* \\ Institute of Virology, Prion Research Group, Technische \\ Universität München, Trogerstr. 30, 81675 Munich, \\ Germany
}

\begin{abstract}
Prion diseases are infectious and fatal neurodegenerative disorders of man and animals which are characterized by spongiform degeneration in the central nervous system. Prion propagation involves the endocytic pathway and endosomal and lysosomal compartments are implicated in trafficking and re-cycling as well as final degradation of prions. Shifting the equilibrium between propagation and lysosomal clearance to the latter impairs cellular prion load. This and earlier findings of autophagic vacuoles in correlation to prion infections both in in vitro and in vivo studies prompted us and others to analyze the role of autophagy in prion infection. Autophagy is a fundamental cellular bulk degradation process for e.g. organelles or cytoplasmic proteins which has many implications for physiology and patho-physiology of cells and whole organisms. In various neurodegenerative disease models mainly protective functions of autophagy were recently described. In this review, we focus on recent findings which correlate autophagy and its manipulations with prion infection scenarios, and discuss perspectives and future directions. The findings summarized here add to the knowledge of the role of autophagy in neurodegeneration and provide interesting new insight into how non-cytosolic aggregated proteins might be subjected to autophagic clearance.
\end{abstract}

\section{Introduction}

Prion diseases are infectious neurodegenerative disorders that can affect humans and animals. Examples for animal prion diseases are scrapie in sheep and goat, bovine spongiform encephalopathy (BSE) in cattle, transmissible mink encephalopathy (TME) in mink, and chronic wasting disease (CWD) in elk and deer. Prion diseases in humans are Creutzfeldt-Jakob disease (CJD), Gerstmann-SträusslerScheinker (GSS) syndrome, fatal familiar insomnia (FFI), kuru, and the new variants of CJD (VCJD and secondary vCJD). The disease is characterized by a rapidly progressing course that leads inevitably to death, usually within a few months. Typically, this is preceded by a long incubation time entirely free of symptoms, lasting for years to many decades in humans. Severe loss of neurons is a key characteristic for all prion diseases, accompanied by strong astrogliosis and mild microglia activation. This results in a progressive spongiform degeneration of the central nervous system (CNS) which manifests itself in ataxia, behavioral changes and, in humans, a highly progressive loss of intellectual

\footnotetext{
\# Both authors contributed equally to this work. *schaetzl@|rz.tum.de
}

abilities (Aguzzi and Polymenidou, 2004; Collinge, 2005; Prusiner, 1998; Weissmann, 2004).

According to the protein-only hypothesis these diseases are caused by prions, proteinaceous infectious particles devoid of encoding nucleic acid (Prusiner, 1982). They consist mainly, if not solely, of an abnormally folded isoform $\left(\mathrm{PrP}^{\mathrm{Sc}}\right)$ of the normal, host-encoded prion protein $\mathrm{PrP}^{\mathrm{C}}$ (Aguzzi and Polymenidou, 2004; Cohen et al., 1994; Prusiner, 1998). Prions have self-propagating capacities in that they are able to catalyze a profound conformational switch from $\mathrm{PrP}^{\mathrm{c}}$ into an aggregated structure resulting finally in the accumulation of misfolded and aggregated $\mathrm{PrPSc}^{\mathrm{Sin}}$ the brain. Hence, prion diseases share profound similarities with other protein misfolding and neurodegenerative diseases like Alzheimer's, Huntington's and Parkinson's disease (Aguzzi and Haass, 2003). Yet, prions are unique as they are not only able to replicate their conformation but are also naturally and experimentally transmissible within and to some extent between species.

In prion-infected cultured neuronal cells (Schatzl et al., 1997) and also in brain biopsy materials of prion-infected patients (Liberski et al., 2008; Sikorska et al., 2004) the appearance of multi-vesicular bodies and autophagic vacuoles has been reported. This prompted us and others to investigate in detail whether there is a link between autophagy and prion infection, in particular as the impact of autophagy in various other neurodegenerative diseases has been recently described (Bursch and Ellinger, 2005; Rubinsztein, 2006).

In this review we focus on the cellular mechanism of autophagy, its regulation, some well-established methods to monitor autophagy, its implications in disease with emphasis on neurodegenerative disorders, and finally, its putative role in prion infection scenarios.

\section{Introducing autophagy}

Degradation of organelles or cytoplasmic proteins can be mediated by an intracellular bulk degradation process called macroautophagy (referred to hereafter as autophagy). One can imagine autophagy, or cellular self-digestion, in its simplest form as single cell's adaptation to starvation: if there is a lack of nutrition in the surroundings, a cell is forced to break down parts of its own reserves to stay alive until the situation improves. During autophagy, portions of the cytosol are engulfed by a membrane sac resulting in a double-membrane vesicle, called autophagosome/ autophagic vacuole, which deliver cytoplasmic cargo to lysosomes (Figure 1). After fusion with lysosomes, the protein and organelle contents of the autophagosome are degraded by acidic lysosomal hydrolases and recycled (Klionsky and Ohsumi, 1999; Yoshimori, 2004) (Figure 1). In single-cell organisms such as yeasts, this starvation response is one of the primary functions of autophagy, but in fact this role extends up to humans. For example, even on a day-to-day basis, autophagy is activated between meals in organs such as the liver to maintain its metabolic functions, supplying amino acids and energy through catabolism (Kuma et al., 2004; Mizushima and Klionsky, 2007). 


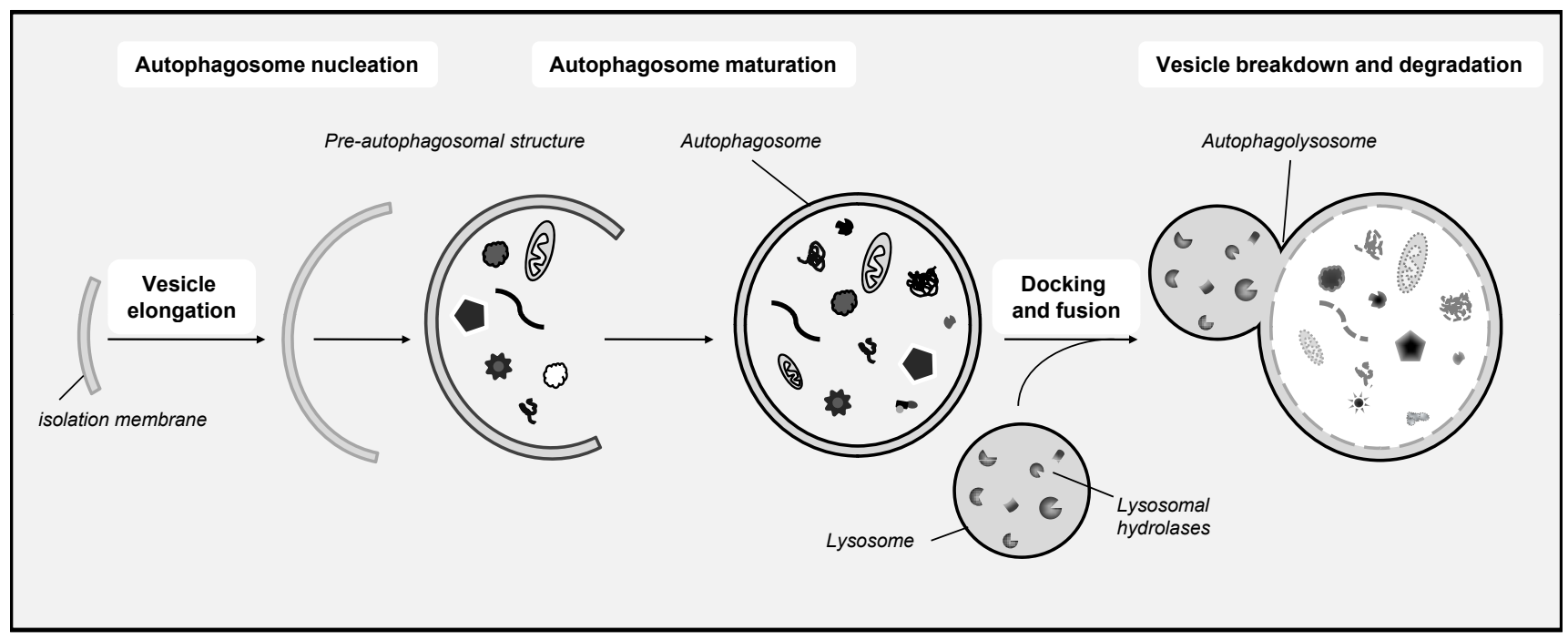

Figure 1. Schematic representation of main cellular steps in macroautophagy.

Autophagosome nucleation starts with an isolation membrane in the cytosol which matures to an autophagosome vesicle. By docking and fusion to lysosomes the content of this autophagolysosome gets access to the lysosomal degradation machinery.

\section{Regulation and manipulation of autophagy}

Autophagy is conserved among eukaryotes and has been characterized from yeast to man (Reggiori and Klionsky, 2002). Basal levels of autophagy are important for maintaining normal cellular homeostasis. As the autophagic process has the capacity for large scale degradation, unregulated degradation of the cytoplasm is likely to be deleterious. Thus, a tight cellular regulation of the autophagic process is important so that it is induced when needed, but otherwise maintained at a basal non-deleterious level.

Several protein kinases regulate autophagy. The best characterized is the mammalian target of rapamycin, mTOR, which is the major inhibitory signal that shuts off autophagy in the presence of growth factors and nutrients (Kamada et al., 2000). Downstream of mTOR, numerous proteins encoded by Atg genes are essential for the execution of autophagy (Levine and Klionsky, 2004). Some of the other regulatory molecules that control autophagy include 5'-AMP-activated protein kinase (AMPK), BH3-only proteins, the inositol 1,4,5-trisphosphate receptor $\left(\mathrm{IP}_{3} \mathrm{R}\right)$, Erk $1 / 2$ and calcium (Criollo et al., 2007; Maiuri et al., 2007; Meijer and Codogno, 2006; Rubinsztein et al., 2007). Autophagy can also be pharmacologically induced by inhibiting negative regulators such as mTOR via the compound rapamycin (Rubinsztein et al., 2007) or by mTOR-independent inducers of autophagy such as trehalose and lithium (Sarkar et al., 2007a; Sarkar et al., 2005). Pharmacological inhibitors of autophagy are for instance 3-methyladenine (3-MA), Wortmannin and LY294002 (Blommaart et al., 1997; Seglen and Gordon, 1982).

Although a complete picture of autophagy regulation is not yet available, breakthroughs in yeast genetics and analysis of mammalian homologues of the autophagyrelated (Atg) proteins identified in yeast (Harding et al., 1995; Suzuki and Ohsumi, 2007; Tsukada and Ohsumi, 1993) have greatly improved the understanding of autophagy and its regulation. Several aspects of regulation mechanisms have recently been reviewed in great detail (Botti et al.,
2006; Gozuacik and Kimchi, 2007; Meijer and Codogno, 2006; Yorimitsu and Klionsky, 2007).

\section{Monitoring autophagy}

Basal and induced levels of autophagy are important with regard to its role in human health and disease. With the rapidly advancing research in the autophagy field a range of biochemical and morphological methods has been developed to monitor autophagy [e.g. reviewed in (Klionsky et al., 2007; Mizushima, 2004)]. These methods are useful and reliable to monitor autophagy in yeast, however, there is some confusion regarding some methods to measure autophagy in higher eukaryotes. A key point in monitoring autophagy is that there is a difference between measurements that monitor the numbers of autophagosomes versus those that measure flux through the autophagic pathway. Thus, a block in autophagic flux, for example due to disturbance in lysosomal function, results in autophagosome accumulation which needs to be differentiated from fully functional autophagy that includes delivery to and degradation within lysosomes (in most higher eukaryotes) or the vacuole (in plants and fungi). Recently, a number of studies about the selection and interpretation of the methods that can be used to examine autophagy and related processes were published, recommending the use of multiple assays to verify an autophagic response (Kawai et al., 2006; Klionsky et al., 2008; Mizushima and Yoshimori, 2007).

\section{Autophagy in physiology and patho-physiology}

Among recent advances, an exciting finding is the striking pleiotropy of autophagy. Beyond its classical role in nutrient supply under starvation and turnover of organelles and proteins, autophagy contributes to various physiological processes such as intracellular cleansing, differentiation, development, longevity, elimination of invading pathogens and antigen transport to the innate and adaptive immune systems or counteracting endoplasmic reticulum stress and diseases characterized by the accumulation of protein 
aggregates (Levine and Kroemer, 2008; Levine and Yuan, 2005; Lum et al., 2005; Maiuri et al., 2007; Mizushima et al., 2008; Yorimitsu and Klionsky, 2007). However, in the context of cancer, potentially this pro-survival function seems to be maladaptive (Mathew et al., 2007). This takes us to the other face of autophagy and its connections to pathophysiology and disease. Besides cancer, autophagy plays a role in a number of infectious and inflammatory diseases and in protein 'unfolding and misfolding' diseases that lead to neuronal, muscle and liver degeneration or heart failure (reviewed in Levine and Deretic, 2007; Levine and Kroemer, 2008; Mizushima et al., 2008).

With respect to the importance of tight regulation of autophagy, perhaps the most fundamental point is that either too little or too much autophagy can be deleterious, a complex balance resulting in its dual role in survival and adaptation or cell death. However, in response to most forms of cellular stress, autophagy plays a cytoprotective role, because Atg gene knockdown/knockout accelerates rather than delays cell death (Levine and Yuan, 2005; Maiuri et al., 2007). Within the cell death research field, autophagy has long been defined as a form of non-apoptotic, or type II, programmed cell death (Clarke, 1990; Kovacs et al., 1986). However, due to the recent findings a consensus is emerging that autophagy might be a cell death impostor which, in reality, functions primarily to promote cellular and organismal health (Kroemer and Levine, 2008).

\section{Autophagy and neurodegenerative diseases}

As mentioned above, autophagy occurs at basal, constitutive levels in the cell. Recent studies have highlighted the importance of basal autophagy in intracellular quality control. The demand for basal autophagy is tissue-specific, though. In liver and other tissues where cells, such as neurons and myocytes, do not divide after differentiation basal autophagy is of great relevance (Hara et al., 2006; Komatsu et al., 2006; Komatsu et al., 2005; Komatsu et al., 2007b; Nakai et al., 2007). Several studies suggest a crucial role of autophagy in neurodegenerative diseases, including Alzheimer's disease, Parkinson's disease, tauopathies and polyglutamine expansion diseases like Huntingon's disease (Berger et al., 2006; Iwata et al., 2005; Mizushima and Hara, 2006; Nixon et al., 2005; Qin et al., 2003; Ravikumar et al., 2002; Rubinsztein, 2006; Rubinsztein et al., 2005; Ventruti and Cuervo, 2007; Webb et al., 2003). A number of in vivo studies during the last years showed that conventional autophagy knockout mice die during embryogenesis or the neonatal period (Fimia et al., 2007; Komatsu et al., 2005; Kuma et al., 2004; Qu et al., 2003; Takahashi et al., 2007; Yue et al., 2003). Mice with neural-tissue-specific knockouts of these genes survive the postnatal starvation period. However, these mice develop progressive motor deficits and display abnormal reflexes, and ubiquitinpositive inclusion bodies accumulate in their neurons (Hara et al., 2006; Komatsu et al., 2006). Studies showed that the CNS, in contrast to other organ systems, displays only low levels of autophagosomes under normal conditions and even after starvation, but it was also demonstrated that constitutive turnover of cytosolic contents by autophagy is indispensable, even in the absence of expression of any disease-associated mutant proteins (Mizushima et al., 2004; Nixon et al., 2005).

Despite the important function of basal autophagy in healthy individuals, the requirement for autophagy is even more evident under disease conditions and levels of autophagosomes can be dramatically increased in injured or degenerating neurons (Petersen et al., 2001). Available data state, beyond any doubt, that autophagy has a beneficial effect of protecting against neurodegeneration. There are several hypotheses about how autophagy can prevent neurodegeneration. However, this is not yet fully understood. One idea is that autophagy eliminates aggregated and aggregate-prone proteins (Bjorkoy et al., 2005; Iwata et al., 2005; Komatsu et al., 2007a; Pankiv et al., 2007; Ravikumar et al., 2002). Concerning Alzheimer's disease and the involvement of autophagy, another hypothesis is that impaired autophagic flux provides a novel site for $A \beta$ peptide production (Yu et al., 2005). Thus, it is reasonable to assume that autophagy could be a therapeutic target for treatment of these neurodegenerative diseases because of its protective role (Rubinsztein et al., 2007).

Recent detailed studies underlined that degradation of disease-related mutant proteins is highly dependent on autophagy, in addition to the ubiquitin-proteasome system. Examples include studies performed with extended polyglutamine-containing proteins that cause various neurodegenerative diseases (Martinez-Vicente and Cuervo, 2007; Rubinsztein, 2006; Rubinsztein et al., 2005). It was shown that the clearance of aggregate-prone proteins, such as mutant huntingtin fragments or mutant forms of a-synuclein causing Huntington's and Parkinson's disease, respectively, can be mediated by autophagy (Ravikumar et al., 2002; Webb et al., 2003). Animal models of Huntington's disease and of other proteinopathies revealed that treatment with rapamycin, a known inducer of autophagy, accelerates the clearance of toxic proteins (Berger et al., 2006; Iwata et al., 2005; Qin et al., 2003; Ravikumar et al., 2004; Shibata et al., 2006). Induction of autophagy, mediated by lithium and trehalose, has been seen to accelerate the clearance of mutant huntingtin and $\alpha$-synucleins (Sarkar et al., 2007a; Sarkar et al., 2005). The beneficial effect of up-regulated autophagy has also been described for other diseases associated with aggregate-prone proteins, such as Alzheimer's disease, forms of motor neuron disease caused by mutations in superoxide dismutase 1 (SOD1), and forms of peripheral neuropathy caused by mutations in peripheral myelin protein 22 (PMP22) (Berger et al., 2006; Fortun et al., 2003; Kabuta et al., 2006).

Moreover, up-regulation of autophagy by regulatory protein kinase complex Target of Rapamycin (TOR) inhibitors such as rapamycin and its analogue $\mathrm{CCl}-779$ protects against neurodegeneration seen in polyglutamine disease models in Drosophila and mice (Ravikumar et al., 2004). Recently, small-molecule enhancers of rapamycin were identified (Sarkar et al., 2007b), which improve the clearance of mutant huntingtin and $\alpha$-synuclein and protect against neurodegeneration in a Drosophila Huntington's disease model. Of note, the effects of small molecule enhancers of rapamycin are independent of TOR, which adds to the possibility of using them in combination with rapamycin for therapeutic purposes. However, it is important to put into consideration that the potential lying in manipulating autophagy as a therapeutic approach for neurodegenerative diseases strongly depends on complex disease-specific factors. On the cellular level, a profound understanding of how the autophagic machinery is involved 
during the pathogenic course of the disease will be relevant. On the whole organism level, the impact of autophagy manipulation will depend on the dynamics of the disease in terms of dissemination and the changes that occur in the organism.

\section{Autophagy and prion infection}

Autophagic vacuoles were described in neurons in experimental models of prion disease in mice and hamsters (Boellaard et al., 1991; Boellaard et al., 1989). In addition, the appearance of multi-vesicular bodies and autophagic vacuoles was observed in prion-infected cultured neuronal cells (Schatzl et al., 1997). More recently, it was found that autophagic vacuoles are formed in neuronal perikarya, neurites and synapses in experimentally induced scrapie, Creutzfeldt-Jakob disease (CJD) and Gerstmann-SträusslerScheinker (GSS) syndrome (Liberski et al., 2004) and autophagic vacuoles were identified in synapses in various forms of human prion disease (Sikorska et al., 2004).

Another interesting correlation between prion diseases and autophagy was observed in studies on scrg1 (scrapie responsive gene 1). This gene was up-regulated in brains of scrapie prion- and BSE-infected mice and in brains of patients with sporadic CJD (Dandoy-Dron et al., 2000; Dandoy-Dron et al., 1998; Dron et al., 1998). In the CNS of prion-infected mice up-regulated Scrg1 was associated with autophagic vacuoles which were observed at the terminal stage of disease (Dron et al., 2005). Consequently, it was suggested that Scrg1 might be useful as a marker for neuronal autophagy in prion diseases (Dron et al., 2006).

With regard to the PrP homologue doppel (Dpl), it was shown that ectopic expression of Dpl in CNS neurons of prion protein knockout-mice $\left(\mathrm{Ngsk} ; \mathrm{NP}^{0 / 0}\right)$ results in lateonset ataxia due to extensive Purkinje cell (PC) death (Moore et al., 1999; Rossi et al., 2001; Sakaguchi et al., 1996). In line with this, it was demonstrated that preceding and during such PC loss the protein levels of both Scrg1 and the well established autophagic markers LC3-II and p62 were increased, whereas mRNA expression levels were stable (Heitz et al., 2008). It was suggested that CNS expression of Dpl might trigger autophagy and that the apoptotic cascade might be triggered by a progressive dysfunction of autophagy.

Besides such descriptions of autophagy in prion disease models, the putative involvement of $\mathrm{PrP}^{\mathrm{c}}$ in autophagic pathways was recently described. An increased expression of LC3-II was observed in hippocampal neurons of Zürich I $\mathrm{Prnp}^{-/-}$mice as compared to wild-type control neurons under serum deprivation and this up-regulation was counter-acted by reintroduction of $\mathrm{PrPc}^{\mathrm{c}}$ into Prnp ${ }^{-/}$cells (Oh et al., 2008). As such counter-regulation was not detectable for $\mathrm{PrP}^{\mathrm{c}}$ lacking the octapeptide region, it was suggested that the octapeptide region of $\mathrm{PrP}^{\mathrm{c}}$ may play a crucial role in control of autophagy in neuronal cells as mediated by $\operatorname{PrP}^{\mathrm{c}}$.

Concerning again the role of autophagy in prion disease, it was proposed that autophagy may contribute to formation of spongiform changes, a pathological hallmark in prionaffected brains, and may be activated by apoptosis (Liberski et al., 2008; Liberski et al., 2002; Liberski et al., 2004). In contrast to this assumption that autophagy plays a diseasepromoting role, it is also quite conceivable that the observed increase in autophagic vacuoles in prion disease models is due to activation of the autophagic machinery as a defense
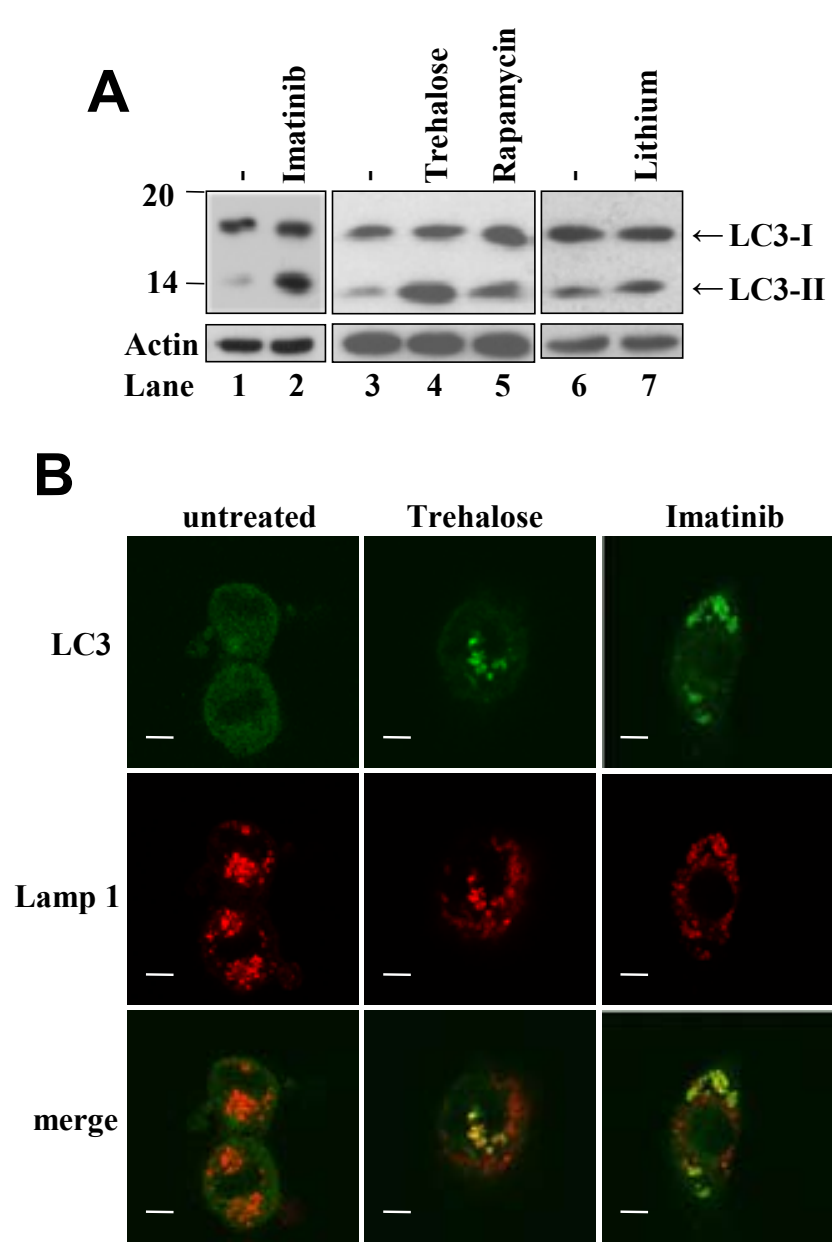

Figure 2. Monitoring autophagosome formation.

(A) ScN2a cells were treated with $10 \mu \mathrm{M}$ imatinib, 100 $\mathrm{mM}$ trehalose, or $200 \mathrm{nM}$ rapamycin for $48 \mathrm{~h}$, or $10 \mathrm{mM}$ lithium for $24 \mathrm{~h}$. Mock-treated cells served as controls. Subsequently, cell lysates were probed in SDS-PAGE using anti-LC3 antibody. Higher amounts of LC3-II are detected in compound-treated cells compared to mock-treated controls, indicating induction of autophagy and autophagosome formation.

(B) ScN2a cells were transfected with GFP-LC3 and either left untreated, treated with $100 \mathrm{mM}$ trehalose or $10 \mu \mathrm{M}$ imatinib for $48 \mathrm{~h}$. Cells were stained with anti-lamp 1 and cy2conjugated secondary antibody and subsequently analyzed by confocal microscopy. Both autophagosome formation (upper panels) and co-localization of autophagosomes and lysosomes (lower panels) is observed in compound-treated cells.

mechanism, leading even to degradation of prions. Support for such a protective role of autophagy in prion disease was described in studies addressing a member of the galactin family of proteins, namely galactin-3. Reduced levels of the lysosomal activation marker LAMP-2 were observed in prion-infected galactin- $3^{-/-}$-mice and, interestingly, in brain tissue of prion-infected wild-type and galactin- $3^{-/-}$-mice, lower mRNA levels of autophagy markers Beclin-1 and Atg5 were detected as compared to mock-infected control brains (Mok et al., 2007). Therefore, the authors suggested 
that endosomal/lysosomal dysfunction in combination with reduced autophagy may contribute to development of prion disease.

Previously, our group showed that imatinib, a drug used to treat chronic myelogenous leukemia, is activating lysosomal degradation of PrPSc (Ertmer et al., 2004) and is at the same time a potent inducer of autophagy and/or autophagosome formation (Ertmer et al., 2007). In prion-infected mice, imatinib treatment at an early phase of peripheral infection delayed both the neuroinvasion of $\mathrm{PrPSc}^{\mathrm{Sc}}$ and the onset of clinical disease (Yun et al., 2007). Unfortunately, drug application at time points when neuroinvasion was already accomplished provoked no clear $\mathrm{PrP}^{\mathrm{Sc}}$ clearance effects in CNS, probably due to ineffective blood-brain barrier crossing of the drug. The beneficial effect of up-regulated autophagy was shown for several neurodegenerative diseases associated with aggregate-prone proteins (Berger et al., 2006; Fortun et al., 2003; Kabuta et al., 2006; Ravikumar et al., 2002; Webb et al., 2003). In line with studies on mutant forms of huntingtin or a-synuclein (Sarkar et al., 2007a; Sarkar et al., 2005) we could recently show that both lithium and trehalose enhance the clearance of PrPSc in prion-infected cells by induction of autophagy (Aguib et al., 2009; Heiseke et al., 2009). As mentioned, a common method to monitor autophagosome formation is to analyse the level of LC3-II which is associated with autophagosome membranes (Kabeya et al., 2000). Chemical compounds used in our studies all increased the amount of LC3-II in prion-infected cells in immunoblot analysis (Figure 2A). LC3 fused to green fluorescent protein (GFP) is another tool to measure induction of autophagosome formation. Prion-infected neuroblastoma ( $\mathrm{ScN} 2 \mathrm{a}$ ) cells treated with autophagy inducing drugs exhibited punctuate GFP staining (exemplarily shown in Figure 2B for trehalose and imatinib), indicating the association of GFP-LC3 with autophagosomal membranes as a result of induction of autophagy.

In our studies we provided the first direct evidence that induction of autophagy results in degradation of cellular $\mathrm{PrP}^{\mathrm{Sc}}$. Inhibition of autophagy by pharmacological interference and siRNA gene-silencing of essential members of the autophagy machinery impaired the capacity of compound-induced autophagy in reducing cellular levels of $\mathrm{PrPSc}$. Of note, as induced autophagy was able to degrade aggregate-prone proteins accumulating within endosomal/lysosomal vesicles, as is the case for $\mathrm{PrPSc}$, we show that autophagy is not only an important clearance route for cytosolic aggregate-prone proteins. Besides compounds inducing autophagy in an mTOR-independent manner (e.g. lithium, trehalose), we studied rapamycin, a drug widely used to activate autophagy by inhibiting mTOR. Rapamycin also reduced the level of cellular $\mathrm{PrPSc}^{\mathrm{Sc}}$, showing that both autophagy inducing pathways, mTOR-dependent and -independent, may be involved in the degradation of $\mathrm{PrPSc}^{\mathrm{S}}$. Reduction of PrPSc in prion-infected ScN2a cells upon treatment with several autophagy inducing drugs is shown in Figure 3.

$\mathrm{PrP}^{\mathrm{c}}$ localizes via a glycosylphosphatidylinositol (GPI)anchor at the outer leaflet of the plasma membrane in cholesterol-and sphingolipid-rich microdomains (Taraboulos et al., 1995) and can move laterally to detergent-soluble domains within the plasma-membrane for subsequent internalization (Sunyach et al., 2003). Therefore, it is possible that upon internalization $\mathrm{PrP}^{\mathrm{c}}$ is in reach of the autophagic

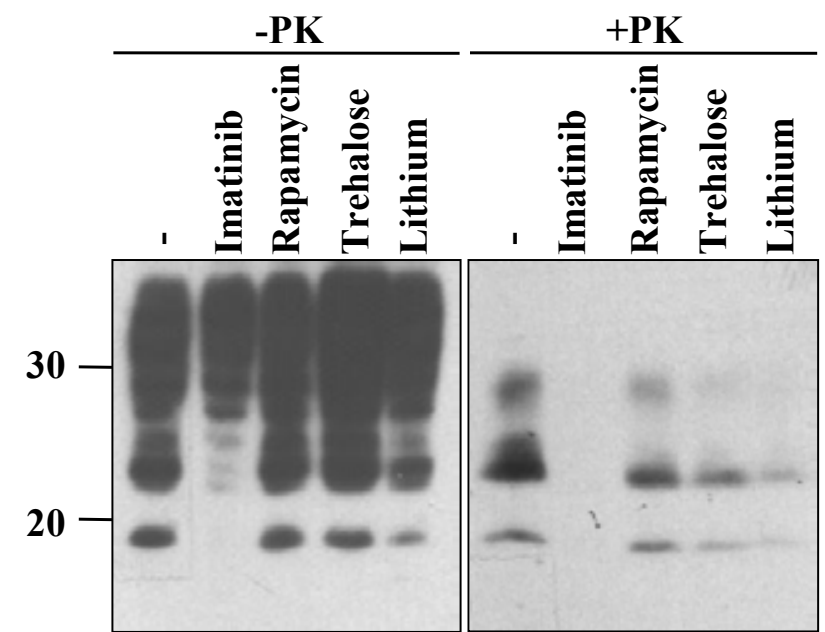

Actin

$\begin{array}{lllllllllll}\text { Lane } & 1 & 2 & 3 & 4 & 5 & 6 & 7 & 8 & 9 & 10\end{array}$

Figure 3. Reduction of PrPSc upon treatment of cells with different autophagy inducing compounds.

ScN2a cells were either left untreated or treated with 10 $\mu \mathrm{M}$ imatinib, $200 \mathrm{nM}$ rapamycin, $100 \mathrm{mM}$ trehalose, or 10 $\mathrm{mM}$ lithium for $48 \mathrm{~h}$ and cell lysates subsequently analyzed by SDS-PAGE using anti-PrP monoclonal antibody $4 \mathrm{H} 11$. Upon PK digestion (lanes 6-10) less PrPSc is observed in compound-treated cells compared to untreated control cells.

degradation machinery. We showed that lithium is not only reducing $\mathrm{PrP}^{\mathrm{Sc}}$ but also levels of $\mathrm{PrP}^{\mathrm{c}}$ in an autophagydependent manner. We observed no reduction of $\mathrm{PrP}^{\mathrm{c}}$ in lithium-treated, autophagy-deficient fibroblasts whereas the level of $\mathrm{PrP}^{\mathrm{c}}$ was slightly but significantly reduced in wildtype fibroblasts upon lithium treatment. In the recent past it has been shown that reduction of $\mathrm{PrP}^{\mathrm{c}}$ by shedding of the protein from the membrane or by down-regulation of $\mathrm{PrP}^{\mathrm{c}}$ reduces conversion of $\mathrm{PrP}^{\mathrm{c}}$ into its pathogenic isoform $\mathrm{PrP}^{\mathrm{Sc}}$ by limiting the amount of $\mathrm{PrP}^{\mathrm{c}}$ substrate available for conversion (Aguib et al., 2008; Heiseke et al., 2008; Marella et al., 2002; Parkin et al., 2004). Therefore, reduction of $\mathrm{PrP}^{\mathrm{c}}$ by lithium-induced autophagy may indirectly contribute to reduction of $\mathrm{PrP}^{\mathrm{Sc}}$ by autophagy. As we did not observe reduced levels of $\mathrm{PrPc}^{\mathrm{c}}$ upon treatment of cells with other autophagy inducing compounds this phenomenon seems to be compound-specific and the exact molecular mechanism remains to be deciphered.

To test whether autophagy-inducing compounds are candidates for therapeutic approaches against prion infection we treated intraperitoneally prion-infected mice (Aguib et al., 2009; Heiseke et al., 2009). Rapamycin treatment of prion-infected mice initiated in the last third of incubation time (i.e. day 100 p.i.), mimicking a pre-clinical therapeutic situation, showed a significant prolongation of prion incubation times as compared to mock-treated control mice. Similar findings were obtained with lithium, although less pronounced (Heiseke et al., 2009). Trehalose treatment did not prolong incubation times, but clearly showed effects on the appearance of $\mathrm{PrPSc}^{\mathrm{Sc}}$ in spleens (Aguib et al., 2009). Depending on when trehalose treatment was started, 


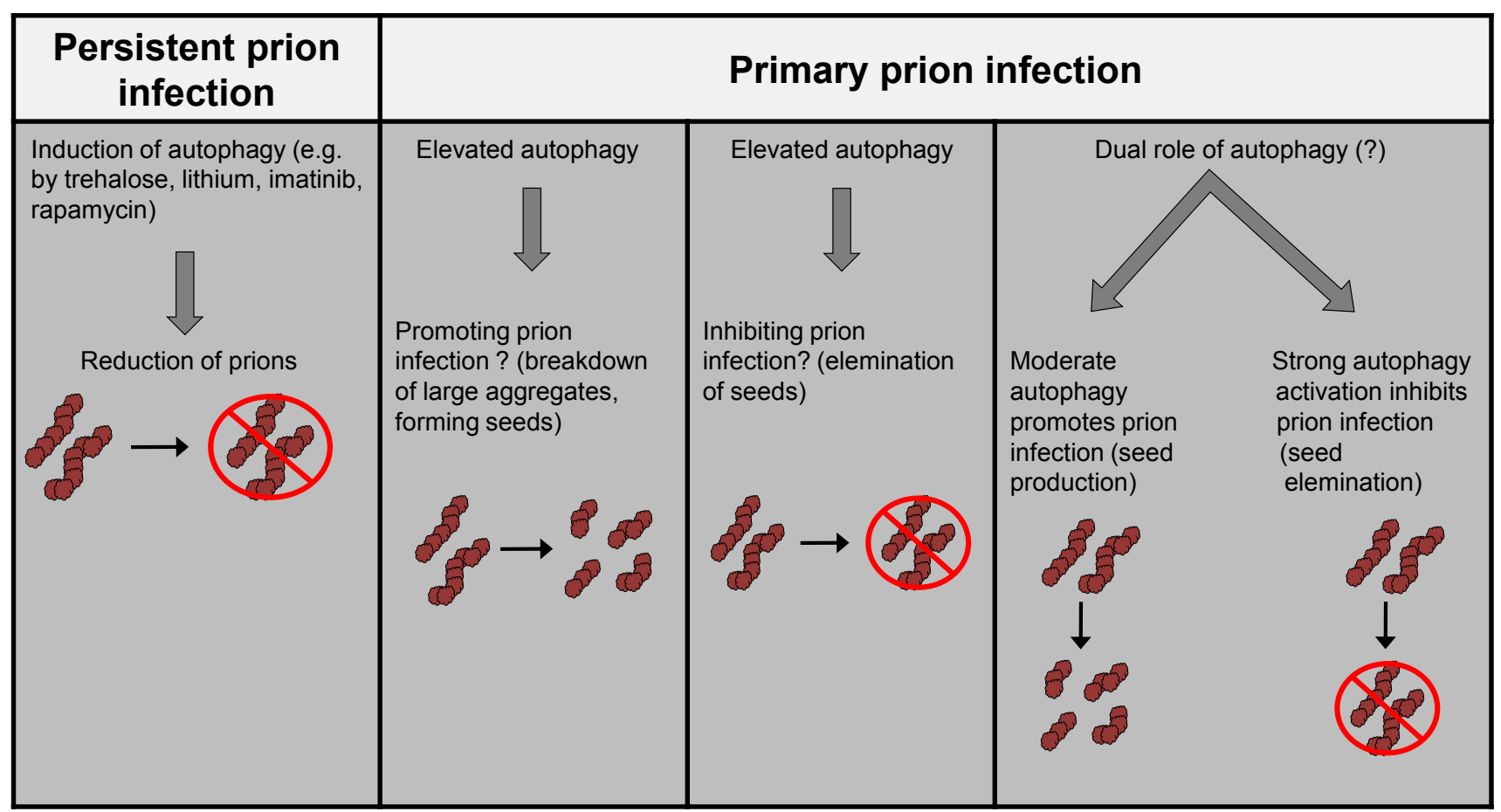

Figure 4. Model of established and putative actions of autophagy in prion infection scenarios.

peripheral accumulation of $\mathrm{PrP}^{\mathrm{Sc}}$ was delayed. As was the case with imatinib treatment, this probably also reflects that the process of neuroinvasion was decelerated. Overall, although still preliminary, these in vivo studies strongly indicate that autophagy inducing compounds are beneficial in prion disease scenarios and ask for further and more complex studies, including also combination of drugs.

\section{More than one role of autophagy in prion infection?}

It is conceivable that the basic process of autophagy has a physiological role in prion infection and might be used by cells for controlling or counter-acting cellular prion infection. In line with this assumption, we observed an increased amount of $\mathrm{PrPSc}$ in cells in which autophagy was reduced by treatment with autophagy inhibitors (Aguib et al., 2009). The increased $\mathrm{PrP}^{\mathrm{Sc}}$ level may result in an increased conversion of $\mathrm{PrP}^{\mathrm{c}}$ into $\mathrm{PrP}^{\mathrm{Sc}}$, subsequently leading to more cellular $\mathrm{PrPSc}^{\mathrm{Sc}}$. In addition, when we assayed for altered regulation of autophagy in primary infection models, a correlation of prion infection and increase in autophagy was obtained (Heiseke, Aguib and Schatzl, personal communication). Manipulation of autophagy in primary prion infection, either increasing or decreasing autophagy, also had reproducible effects on primary prion infection.

Besides more detailed in vitro studies appropriate in vivo experiments are required to elucidate the impact of autophagy on prion infection and to validate whether autophagy plays a general role in prion disease scenarios. One possibility is using mice expressing GFP-LC3, allowing direct correlation analysis of hallmarks of prion infection and autophagy in vivo (Baier, Aguib, Heiseke and Schatzl, personal communication). As presently available mice with a neuron-specific conditional knockout of Atg5 or Atg7 die soon after birth at time points which make them not accessible for classical prion infection studies, alternative Cre deleter mice have to be crossed in, in order to generate a neuron-specific and postnatal knockout of these genes. This would enable to directly assess the impact of autophagy in prion incubation time and prion disease in in vivo models, due to increased life-span of neuron-specific Atg knockout mice.

Although there is now good evidence from our work that induction of autophagy is beneficial in prion-infected cells and animals, it is not clear whether increased or decreased autophagy also can have deleterious effects. One scenario would be that cells impaired in autophagy might be more susceptible to prion infection as they are lacking a putative defence mechanism. In primary infection models we started to test whether increase or decrease of basal autophagy is a modifier of prion infection and susceptibility to prion infection. Another possibility worth to envision is that autophagy also might be a positive factor for prion propagation. A moderate basal level of cellular autophagy, that is likely to be present even in treatment situations with autophagy inhibitors, might be beneficial for generating smaller $\mathrm{PrPSc}^{\mathrm{Sc}}$ seeds, which are known to be more efficient templates for conversion of $\mathrm{PrP}^{\mathrm{c}}$ into PrPSc than are larger aggregates (Silveira et al., 2005). Hence, although induced autophagy can reduce or clear prions and $\mathrm{PrPSc}^{\mathrm{Sc}}$ seeds, a moderate level of autophagy might support $\mathrm{PrP}^{\mathrm{Sc}}$ seed production at certain stages of prion infection, thereby promoting prion disease. Experimental evidence for this was obtained when we tried to infect fibroblasts from Atg $5^{-/-}$mice with murine prions (Heiseke, Aguib and Schatzl, personal communication). Whereas wild-type fibroblasts could readily be infected with prions, knockout fibroblasts were significantly less infectable. Re-introduction of Atg5 via lentiviral transduction clearly improved this deficiency 
in primary prion infection (Heiseke, Aguib and Schatzl, personal communication). This provides reliable evidence that a certain level of autophagy can be both a positive modifier of prion infection and a supporting factor, which in certain scenarios is even essential for prion propagation. As outlined in Figure 4, a combination of anti-prion and prionpromoting effects of autophagy cannot be excluded as well. This remains us with a scenario reminding of the seeming paradox of the role of autophagy in cell death and cancer biology (Mizushima et al., 2008).

\section{Conclusions and future directions}

The systematic analysis of autophagy in prion infection scenarios is still rather incomplete. From what is found so far there is good experimental evidence from in vitro and partly also in vivo studies that induction of autophagy, e.g. by chemical compounds, can clearly have beneficial effects on prion infection. The cellular load of $\mathrm{PrPSc}^{\mathrm{Sc}}$ and prion infectivity is reduced, most probably by an increase in lysosomal degradation, shifting the equilibrium between prion propagation and clearance towards the latter. The exact molecular mechanisms are still incompletely understood, in particular as the very vast majority of $\mathrm{PrP}^{\mathrm{Sc}} /$ prions reside within endosomal and lysosomal vesicles. On the other hand this clearly shows that not only cytosolic materials are prone to autophagic degradation. In future work it has to be studied how prion propagation, prion trafficking and recycling, and finally prion clearance are interconnected with the autophagic pathway. In addition, more work is needed to elucidate whether induction of autophagy in this context has to be mTOR-dependent, -independent, or both. Finally, bringing this knowledge to translational research and bridging therapeutic anti-prion concepts will be extremely difficult, as it is with basically all other anti-prion strategies so far. Besides suboptimal pharmacokinetics and possible side effects the ultralarge obstacle rests with ineffective passing of the blood-brain-barrier. This does not exclude effects in post-exposure situations in peripheral prion infection scenarios and a sophisticated combination of compounds which target divers 'anti-prion' pathways still is a reasonable goal.

The biological function of autophagy per se in prion infection and disease is still searching answers. Preliminary data indicate that the cellular level of autophagy can be a modifier of susceptibility to prion infection, although at present it is still difficult to dissect whether changes in autophagy are a pre-requisite or consequence of cellular prion infection. Questions like this are readily accessible in in vitro studies. As mentioned, autophagy might also have a dual function and there might be situations in which autophagy is needed for prion propagation. Work from yeast prions and nowadays from mammalian cell culture systems for studying prion-like properties (Krammer et al., 2009) indicates that the kinetics of aggregate formation needs breaking-up of aggregates and fibrils, probably involving disaggregase activities. It will be interesting to study whether autophagy is a cellular mechanism involved in this scenario.

Another challenge will be to establish reliable in vivo models for studying prion infection and autophagy side by side. Faced with early lethality in Atg knockout mice, one way to go might be crossing the available conditional knockout mice, which are neuron-specifically floxed, with alternative Cre deleter mice to gain both postnatal knockout and prolonged life time which then allows performing standard prion incubation time assays.

In summary, there seems to be a fascinating interplay between prion infections and autophagy. Although extensive future studies will be necessary, there is a high probability that it is both worth and feasible to decipher their mutual interaction at a molecular level.

\section{Acknowledgements}

This work was supported by SFB-596 (project A8), APRI Canada, and was performed within the framework of European Union FP6 Network of Excellence 'Neuroprion'. Y.A. was supported by grants from Technische Universität München (TUM) and the German Academic Exchange Service (DAAD).

\section{References}

Aguib, Y., Gilch, S., Krammer, C., Ertmer, A., Groschup, M.H., and Schatzl, H.M. (2008). Neuroendocrine cultured cells counteract persistent prion infection by downregulation of $\mathrm{PrPc}$. Molecular and cellular neurosciences 38, 98-109.

Aguib, Y., Heiseke, A., Gilch, S., Riemer, C., Baier, M., Schatzl, H.M., and Ertmer, A. (2009). Autophagy induction by trehalose counteracts cellular prion infection. Autophagy 5, 361-369.

Aguzzi, A., and Haass, C. (2003). Games played by rogue proteins in prion disorders and Alzheimer's disease. Science (New York, NY 302, 814-818.

Aguzzi, A., and Polymenidou, M. (2004). Mammalian prion biology: one century of evolving concepts. Cell 116, 313-327.

Berger, Z., Ravikumar, B., Menzies, F.M., Oroz, L.G., Underwood, B.R., Pangalos, M.N., Schmitt, I., Wullner, U., Evert, B.O., O'Kane, C.J., et al. (2006). Rapamycin alleviates toxicity of different aggregate-prone proteins. Human molecular genetics 15, 433-442.

Bjorkoy, G., Lamark, T., Brech, A., Outzen, H., Perander, M., Overvatn, A., Stenmark, H., and Johansen, T. (2005). p62/SQSTM1 forms protein aggregates degraded by autophagy and has a protective effect on huntingtininduced cell death. The Journal of cell biology 171, 603-614.

Blommaart, E.F., Krause, U., Schellens, J.P., VreelingSindelarova, H., and Meijer, A.J. (1997). The phosphatidylinositol 3-kinase inhibitors wortmannin and LY294002 inhibit autophagy in isolated rat hepatocytes. European journal of biochemistry / FEBS 243, 240-246.

Boellaard, J.W., Kao, M., Schlote, W., and Diringer, H. (1991). Neuronal autophagy in experimental scrapie. Acta neuropathologica 82, 225-228.

Boellaard, J.W., Schlote, W., and Tateishi, J. (1989). Neuronal autophagy in experimental Creutzfeldt-Jakob's disease. Acta neuropathologica 78, 410-418.

Botti, J., Djavaheri-Mergny, M., Pilatte, Y., and Codogno, P. (2006). Autophagy signaling and the cogwheels of cancer. Autophagy 2, 67-73.

Bursch, W., and Ellinger, A. (2005). Autophagy--a basic mechanism and a potential role for neurodegeneration. Folia neuropathologica / Association of Polish Neuropathologists and Medical Research Centre, Polish Academy of Sciences 43, 297-310. 
Clarke, P.G. (1990). Developmental cell death: morphological diversity and multiple mechanisms. Anatomy and embryology 181, 195-213.

Cohen, F.E., Pan, K.M., Huang, Z., Baldwin, M., Fletterick, R.J., and Prusiner, S.B. (1994). Structural clues to prion replication. Science (New York, NY 264, 530-531.

Criollo, A., Maiuri, M.C., Tasdemir, E., Vitale, I., Fiebig, A.A., Andrews, D., Molgo, J., Diaz, J., Lavandero, S., Harper, F., et al. (2007). Regulation of autophagy by the inositol trisphosphate receptor. Cell death and differentiation 14 , 1029-1039.

Dandoy-Dron, F., Benboudjema, L., Guillo, F., Jaegly, A., Jasmin, C., Dormont, D., Tovey, M.G., and Dron, M. (2000). Enhanced levels of scrapie responsive gene mRNA in BSE-infected mouse brain. Brain research 76 , 173-179.

Dandoy-Dron, F., Guillo, F., Benboudjema, L., Deslys, J.P., Lasmezas, C., Dormont, D., Tovey, M.G., and Dron, M. (1998). Gene expression in scrapie. Cloning of a new scrapie-responsive gene and the identification of increased levels of seven other mRNA transcripts. The Journal of biological chemistry 273, 7691-7697.

Dron, M., Bailly, Y., Beringue, V., Haeberle, A.M., Griffond, B., Risold, P.Y., Tovey, M.G., Laude, H., and Dandoy-Dron, F. (2005). Scrg1 is induced in TSE and brain injuries, and associated with autophagy. The European journal of neuroscience 22, 133-146.

Dron, M., Bailly, Y., Beringue, V., Haeberle, A.M., Griffond, B., Risold, P.Y., Tovey, M.G., Laude, H., and DandoyDron, F. (2006). SCRG1, a potential marker of autophagy in transmissible spongiform encephalopathies. Autophagy 2, 58-60.

Dron, M., Dandoy-Dron, F., Guillo, F., Benboudjema, L., Hauw, J.J., Lebon, P., Dormont, D., and Tovey, M.G. (1998). Characterization of the human analogue of a Scrapie-responsive gene. The Journal of biological chemistry 273, 18015-18018.

Ertmer, A., Gilch, S., Yun, S.W., Flechsig, E., Klebl, B., Stein-Gerlach, M., Klein, M.A., and Schatzl, H.M. (2004). The tyrosine kinase inhibitor STI571 induces cellular clearance of PrPSc in prion-infected cells. The Journal of biological chemistry 279, 41918-41927.

Ertmer, A., Huber, V., Gilch, S., Yoshimori, T., Erfle, V., Duyster, J., Elsasser, H.P., and Schatzl, H.M. (2007). The anticancer drug imatinib induces cellular autophagy. Leukemia 21, 936-942.

Fimia, G.M., Stoykova, A., Romagnoli, A., Giunta, L., Di Bartolomeo, S., Nardacci, R., Corazzari, M., Fuoco, C., Ucar, A., Schwartz, P., et al. (2007). Ambra1 regulates autophagy and development of the nervous system. Nature 447, 1121-1125.

Fortun, J., Dunn, W.A., Jr., Joy, S., Li, J., and Notterpek, L. (2003). Emerging role for autophagy in the removal of aggresomes in Schwann cells. J Neurosci 23, 10672-10680.

Gozuacik, D., and Kimchi, A. (2007). Autophagy and cell death. Current topics in developmental biology 78 , 217-245.

Hara, T., Nakamura, K., Matsui, M., Yamamoto, A., Nakahara, Y., Suzuki-Migishima, R., Yokoyama, M., Mishima, K., Saito, I., Okano, H., et al. (2006). Suppression of basal autophagy in neural cells causes neurodegenerative disease in mice. Nature 441, 885-889.
Harding, T.M., Morano, K.A., Scott, S.V., and Klionsky, D.J. (1995). Isolation and characterization of yeast mutants in the cytoplasm to vacuole protein targeting pathway. The Journal of cell biology 131, 591-602.

Heiseke, A., Aguib, Y., Riemer, C., Baier, M., and Schatzl, H.M. (2009). Lithium induces clearance of protease resistant prion protein in prion-infected cells by induction of autophagy. Journal of neurochemistry 109, 25-34.

Heiseke, A., Schobel, S., Lichtenthaler, S.F., Vorberg, I., Groschup, M.H., Kretzschmar, H., Schatzl, H.M., and Nunziante, M. (2008). The novel sorting nexin SNX33 interferes with cellular PrP formation by modulation of $\operatorname{PrP}$ shedding. Traffic 9, 1116-1129.

Heitz, S., Grant, N.J., Leschiera, R., Haeberle, A.M., Demais, V., Bombarde, G., and Bailly, Y. (2008). Autophagy and Cell Death of Purkinje Cells Overexpressing Doppel in Ngsk Prnp-deficient Mice. Brain pathology (Zurich, Switzerland).

Iwata, A., Riley, B.E., Johnston, J.A., and Kopito, R.R. (2005). HDAC6 and microtubules are required for autophagic degradation of aggregated huntingtin. The Journal of biological chemistry 280, 40282-40292.

Kabeya, Y., Mizushima, N., Ueno, T., Yamamoto, A., Kirisako, T., Noda, T., Kominami, E., Ohsumi, Y., and Yoshimori, T. (2000). LC3, a mammalian homologue of yeast Apg8p, is localized in autophagosome membranes after processing. The EMBO journal 19, 5720-5728.

Kabuta, T., Suzuki, Y., and Wada, K. (2006). Degradation of amyotrophic lateral sclerosis-linked mutant $\mathrm{Cu}, \mathrm{Zn}$ superoxide dismutase proteins by macroautophagy and the proteasome. The Journal of biological chemistry 281 , 30524-30533.

Kamada, Y., Funakoshi, T., Shintani, T., Nagano, K., Ohsumi, M., and Ohsumi, Y. (2000). Tor-mediated induction of autophagy via an Apg1 protein kinase complex. The Journal of cell biology 150, 1507-1513.

Kawai, A., Takano, S., Nakamura, N., and Ohkuma, S. (2006). Quantitative monitoring of autophagic degradation. Biochemical and biophysical research communications 351, 71-77.

Klionsky, D.J., Abeliovich, H., Agostinis, P., Agrawal, D.K., Aliev, G., Askew, D.S., Baba, M., Baehrecke, E.H., Bahr, B.A., Ballabio, A., et al. (2008). Guidelines for the use and interpretation of assays for monitoring autophagy in higher eukaryotes. Autophagy 4, 151-175.

Klionsky, D.J., Cuervo, A.M., and Seglen, P.O. (2007). Methods for monitoring autophagy from yeast to human. Autophagy 3, 181-206.

Klionsky, D.J., and Ohsumi, Y. (1999). Vacuolar import of proteins and organelles from the cytoplasm. Annual review of cell and developmental biology 15, 1-32.

Komatsu, M., Ueno, T., Waguri, S., Uchiyama, Y., Kominami, E., and Tanaka, K. (2007a). Constitutive autophagy: vital role in clearance of unfavorable proteins in neurons. Cell death and differentiation 14, 887-894.

Komatsu, M., Waguri, S., Chiba, T., Murata, S., Iwata, J., Tanida, I., Ueno, T., Koike, M., Uchiyama, Y., Kominami, E., et al. (2006). Loss of autophagy in the central nervous system causes neurodegeneration in mice. Nature 441 , 880-884.

Komatsu, M., Waguri, S., Ueno, T., Iwata, J., Murata, S., Tanida, I., Ezaki, J., Mizushima, N., Ohsumi, Y., Uchiyama, Y., et al. (2005). Impairment of starvation-induced and 
constitutive autophagy in Atg7-deficient mice. The Journal of cell biology 169, 425-434.

Komatsu, M., Wang, Q.J., Holstein, G.R., Friedrich, V.L., Jr., Iwata, J., Kominami, E., Chait, B.T., Tanaka, K., and Yue, Z. (2007b). Essential role for autophagy protein Atg7 in the maintenance of axonal homeostasis and the prevention of axonal degeneration. Proceedings of the National Academy of Sciences of the United States of America 104, 14489-14494.

Kovacs, J., Fellinger, E., Karpati, P.A., Kovacs, A.L., and Laszlo, L. (1986). The turnover of autophagic vacuoles: evaluation by quantitative electron microscopy. Biomedica biochimica acta 45, 1543-1547.

Krammer, C., Kryndushkin, D., Suhre, M.H., Kremmer, E., Hofmann, A., Pfeifer, A., Scheibel, T., Wickner, R.B., Schatzl, H.M., and Vorberg, I. (2009). The yeast Sup35NM domain propagates as a prion in mammalian cells. Proceedings of the National Academy of Sciences of the United States of America 106, 462-467.

Kroemer, G., and Levine, B. (2008). Autophagic cell death: the story of a misnomer. Nat Rev Mol Cell Biol 9, 1004-1010.

Kuma, A., Hatano, M., Matsui, M., Yamamoto, A., Nakaya, H., Yoshimori, T., Ohsumi, Y., Tokuhisa, T., and Mizushima, N. (2004). The role of autophagy during the early neonatal starvation period. Nature 432, 1032-1036.

Levine, B., and Deretic, V. (2007). Unveiling the roles of autophagy in innate and adaptive immunity. Nat Rev Immunol 7, 767-777.

Levine, B., and Klionsky, D.J. (2004). Development by selfdigestion: molecular mechanisms and biological functions of autophagy. Developmental cell 6, 463-477.

Levine, B., and Kroemer, G. (2008). Autophagy in the pathogenesis of disease. Cell 132, 27-42.

Levine, B., and Yuan, J. (2005). Autophagy in cell death: an innocent convict? The Journal of clinical investigation 115, 2679-2688.

Liberski, P.P., Brown, D.R., Sikorska, B., Caughey, B., and Brown, P. (2008). Cell death and autophagy in prion diseases (transmissible spongiform encephalopathies). Folia neuropathologica / Association of Polish Neuropathologists and Medical Research Centre, Polish Academy of Sciences 46, 1-25.

Liberski, P.P., Gajdusek, D.C., and Brown, P. (2002). How do neurons degenerate in prion diseases or transmissible spongiform encephalopathies (TSEs): neuronal autophagy revisited. Acta neurobiologiae experimentalis 62, 141-147.

Liberski, P.P., Sikorska, B., Bratosiewicz-Wasik, J., Gajdusek, D.C., and Brown, P. (2004). Neuronal cell death in transmissible spongiform encephalopathies (prion diseases) revisited: from apoptosis to autophagy. The international journal of biochemistry \& cell biology 36 , 2473-2490.

Lum, J.J., DeBerardinis, R.J., and Thompson, C.B. (2005). Autophagy in metazoans: cell survival in the land of plenty. Nat Rev Mol Cell Biol 6, 439-448.

Maiuri, M.C., Zalckvar, E., Kimchi, A., and Kroemer, G. (2007). Self-eating and self-killing: crosstalk between autophagy and apoptosis. Nat Rev Mol Cell Biol 8, 741-752.

Marella, M., Lehmann, S., Grassi, J., and Chabry, J. (2002). Filipin prevents pathological prion protein accumulation by reducing endocytosis and inducing cellular PrP release. The Journal of biological chemistry 277, 25457-25464.

Martinez-Vicente, M., and Cuervo, A.M. (2007). Autophagy and neurodegeneration: when the cleaning crew goes on strike. Lancet neurology 6, 352-361.

Mathew, R., Karantza-Wadsworth, V., and White, E. (2007). Role of autophagy in cancer. Nat Rev Cancer 7, 961-967.

Meijer, A.J., and Codogno, P. (2006). Signalling and autophagy regulation in health, aging and disease. Molecular aspects of medicine 27, 411-425.

Mizushima, N. (2004). Methods for monitoring autophagy. The international journal of biochemistry \& cell biology 36 , 2491-2502.

Mizushima, N., and Hara, T. (2006). Intracellular quality control by autophagy: how does autophagy prevent neurodegeneration? Autophagy 2, 302-304.

Mizushima, N., and Klionsky, D.J. (2007). Protein turnover via autophagy: implications for metabolism. Annual review of nutrition $27,19-40$.

Mizushima, N., Levine, B., Cuervo, A.M., and Klionsky, D.J. (2008). Autophagy fights disease through cellular selfdigestion. Nature 451, 1069-1075.

Mizushima, N., Yamamoto, A., Matsui, M., Yoshimori, T., and Ohsumi, Y. (2004). In vivo analysis of autophagy in response to nutrient starvation using transgenic mice expressing a fluorescent autophagosome marker. Molecular biology of the cell 15, 1101-1111.

Mizushima, N., and Yoshimori, T. (2007). How to interpret LC3 immunoblotting. Autophagy 3, 542-545.

Mok, S.W., Riemer, C., Madela, K., Hsu, D.K., Liu, F.T., Gultner, S., Heise, I., and Baier, M. (2007). Role of galectin-3 in prion infections of the CNS. Biochemical and biophysical research communications 359, 672-678.

Moore, R.C., Lee, I.Y., Silverman, G.L., Harrison, P.M., Strome, R., Heinrich, C., Karunaratne, A., Pasternak, S.H., Chishti, M.A., Liang, Y., et al. (1999). Ataxia in prion protein (PrP)-deficient mice is associated with upregulation of the novel PrP-like protein doppel. Journal of molecular biology 292, 797-817.

Nakai, A., Yamaguchi, O., Takeda, T., Higuchi, Y., Hikoso, S., Taniike, M., Omiya, S., Mizote, I., Matsumura, Y., Asahi, M., et al. (2007). The role of autophagy in cardiomyocytes in the basal state and in response to hemodynamic stress. Nature medicine 13, 619-624.

Nixon, R.A., Wegiel, J., Kumar, A., Yu, W.H., Peterhoff, C., Cataldo, A., and Cuervo, A.M. (2005). Extensive involvementofautophagyinAlzheimerdisease:animmunoelectron microscopy study. Journal of neuropathology and experimental neurology 64, 113-122.

Oh, J.M., Shin, H.Y., Park, S.J., Kim, B.H., Choi, J.K., Choi, E.K., Carp, R.I., and Kim, Y.S. (2008). The involvement of cellular prion protein in the autophagy pathway in neuronal cells. Molecular and cellular neurosciences 39 , 238-247.

Pankiv, S., Clausen, T.H., Lamark, T., Brech, A., Bruun, J.A., Outzen, H., Overvatn, A., Bjorkoy, G., and Johansen, T. (2007). p62/SQSTM1 binds directly to Atg8/LC3 to facilitate degradation of ubiquitinated protein aggregates by autophagy. The Journal of biological chemistry 282 , 24131-24145.

Parkin, E.T., Watt, N.T., Turner, A.J., and Hooper, N.M. (2004). Dual mechanisms for shedding of the cellular 
prion protein. The Journal of biological chemistry 279, 11170-11178.

Petersen, A., Larsen, K.E., Behr, G.G., Romero, N., Przedborski, S., Brundin, P., and Sulzer, D. (2001). Expanded CAG repeats in exon 1 of the Huntington's disease gene stimulate dopamine-mediated striatal neuron autophagy and degeneration. Human molecular genetics 10, 1243-1254.

Prusiner, S.B. (1982). Novel proteinaceous infectious particles cause scrapie. Science (New York, NY 216, 136-144.

Prusiner, S.B. (1998). Prions. Proceedings of the National Academy of Sciences of the United States of America 95, 13363-13383.

Qin, Z.H., Wang, Y., Kegel, K.B., Kazantsev, A., Apostol, B.L., Thompson, L.M., Yoder, J., Aronin, N., and DiFiglia, M. (2003). Autophagy regulates the processing of amino terminal huntingtin fragments. Human molecular genetics 12, 3231-3244.

Qu, X., Yu, J., Bhagat, G., Furuya, N., Hibshoosh, H., Troxel, A., Rosen, J., Eskelinen, E.L., Mizushima, N., Ohsumi, Y., et al. (2003). Promotion of tumorigenesis by heterozygous disruption of the beclin 1 autophagy gene. The Journal of clinical investigation 112, 1809-1820.

Ravikumar, B., Duden, R., and Rubinsztein, D.C. (2002). Aggregate-prone proteins with polyglutamine and polyalanine expansions are degraded by autophagy. Human molecular genetics 11, 1107-1117.

Ravikumar, B., Vacher, C., Berger, Z., Davies, J.E., Luo, S., Oroz, L.G., Scaravilli, F., Easton, D.F., Duden, R., O'Kane, C.J., et al. (2004). Inhibition of mTOR induces autophagy and reduces toxicity of polyglutamine expansions in fly and mouse models of Huntington disease. Nature genetics 36, 585-595.

Reggiori, F., and Klionsky, D.J. (2002). Autophagy in the eukaryotic cell. Eukaryotic cell 1, 11-21.

Rossi, D., Cozzio, A., Flechsig, E., Klein, M.A., Rulicke, T., Aguzzi, A., and Weissmann, C. (2001). Onset of ataxia and Purkinje cell loss in PrP null mice inversely correlated with Dpl level in brain. The EMBO journal 20,694-702.

Rubinsztein, D.C. (2006). The roles of intracellular proteindegradation pathways in neurodegeneration. Nature 443, 780-786.

Rubinsztein, D.C., DiFiglia, M., Heintz, N., Nixon, R.A., Qin, Z.H., Ravikumar, B., Stefanis, L., and Tolkovsky, A. (2005). Autophagy and its possible roles in nervous system diseases, damage and repair. Autophagy 1, 11-22.

Rubinsztein, D.C., Gestwicki, J.E., Murphy, L.O., and Klionsky, D.J. (2007). Potential therapeutic applications of autophagy. Nat Rev Drug Discov 6, 304-312.

Sakaguchi, S., Katamine, S., Nishida, N., Moriuchi, R., Shigematsu, K., Sugimoto, T., Nakatani, A., Kataoka, Y., Houtani, T., Shirabe, S., et al. (1996). Loss of cerebellar Purkinje cells in aged mice homozygous for a disrupted PrP gene. Nature 380, 528-531.

Sarkar, S., Davies, J.E., Huang, Z., Tunnacliffe, A., and Rubinsztein, D.C. (2007a). Trehalose, a novel mTORindependent autophagy enhancer, accelerates the clearance of mutant huntingtin and alpha-synuclein. The Journal of biological chemistry 282, 5641-5652.

Sarkar, S., Floto, R.A., Berger, Z., Imarisio, S., Cordenier, A., Pasco, M., Cook, L.J., and Rubinsztein, D.C. (2005). Lithium induces autophagy by inhibiting inositol monophosphatase. The Journal of cell biology 170 , 1101-1111.

Sarkar, S., Perlstein, E.O., Imarisio, S., Pineau, S., Cordenier, A., Maglathlin, R.L., Webster, J.A., Lewis, T.A., O'Kane, C.J., Schreiber, S.L., et al. (2007b). Small molecules enhance autophagy and reduce toxicity in Huntington's disease models. Nature chemical biology 3, 331-338.

Schatzl, H.M., Laszlo, L., Holtzman, D.M., Tatzelt, J., DeArmond, S.J., Weiner, R.I., Mobley, W.C., and Prusiner, S.B. (1997). A hypothalamic neuronal cell line persistently infected with scrapie prions exhibits apoptosis. Journal of virology 71, 8821-8831.

Seglen, P.O., and Gordon, P.B. (1982). 3-Methyladenine: specific inhibitor of autophagic/lysosomal protein degradation in isolated rat hepatocytes. Proceedings of the National Academy of Sciences of the United States of America 79, 1889-1892.

Shibata, M., Lu, T., Furuya, T., Degterev, A., Mizushima, N., Yoshimori, T., MacDonald, M., Yankner, B., and Yuan, J. (2006). Regulation of intracellular accumulation of mutant Huntingtin by Beclin 1. The Journal of biological chemistry 281, 14474-14485.

Sikorska, B., Liberski, P.P., Giraud, P., Kopp, N., and Brown, P. (2004). Autophagy is a part of ultrastructural synaptic pathology in Creutzfeldt-Jakob disease: a brain biopsy study. The international journal of biochemistry \& cell biology 36, 2563-2573.

Silveira, J.R., Raymond, G.J., Hughson, A.G., Race, R.E., Sim, V.L., Hayes, S.F., and Caughey, B. (2005). The most infectious prion protein particles. Nature 437, 257-261.

Sunyach, C., Jen, A., Deng, J., Fitzgerald, K.T., Frobert, Y., Grassi, J., McCaffrey, M.W., and Morris, R. (2003). The mechanism of internalization of glycosylphosphatidylinositol-anchored prion protein. The EMBO journal 22, 3591-3601.

Suzuki, K., and Ohsumi, Y. (2007). Molecular machinery of autophagosome formation in yeast, Saccharomyces cerevisiae. FEBS letters 581, 2156-2161.

Takahashi, Y., Coppola, D., Matsushita, N., Cualing, H.D., Sun, M., Sato, Y., Liang, C., Jung, J.U., Cheng, J.Q., Mule, J.J., et al. (2007). Bif-1 interacts with Beclin 1 through UVRAG and regulates autophagy and tumorigenesis. Nature cell biology 9, 1142-1151.

Taraboulos, A., Scott, M., Semenov, A., Avrahami, D., Laszlo, L., and Prusiner, S.B. (1995). Cholesterol depletion and modification of $\mathrm{COOH}$-terminal targeting sequence of the prion protein inhibit formation of the scrapie isoform. The Journal of cell biology 129, 121-132.

Tsukada, M., and Ohsumi, Y. (1993). Isolation and characterization of autophagy-defective mutants of Saccharomyces cerevisiae. FEBS letters 333, 169-174.

Ventruti, A., and Cuervo, A.M. (2007). Autophagy and neurodegeneration. Current neurology and neuroscience reports 7, 443-451.

Webb, J.L., Ravikumar, B., Atkins, J., Skepper, J.N., and Rubinsztein, D.C. (2003). Alpha-Synuclein is degraded by both autophagy and the proteasome. The Journal of biological chemistry 278, 25009-25013.

Yorimitsu, T., and Klionsky, D.J. (2007). Eating the endoplasmic reticulum: quality control by autophagy. Trends in cell biology 17, 279-285.

Yoshimori, T. (2004). Autophagy: a regulated bulk degradation process inside cells. Biochemical and biophysical research communications 313, 453-458. 
Yu, W.H., Cuervo, A.M., Kumar, A., Peterhoff, C.M., Schmidt, S.D., Lee, J.H., Mohan, P.S., Mercken, M., Farmery, M.R., Tjernberg, L.O., et al. (2005). Macroautophagy--a novel Beta-amyloid peptide-generating pathway activated in Alzheimer's disease. The Journal of cell biology 171, 87-98.

Yue, Z., Jin, S., Yang, C., Levine, A.J., and Heintz, N. (2003). Beclin 1, an autophagy gene essential for early embryonic development, is a haploinsufficient tumor suppressor. Proceedings of the National Academy of Sciences of the United States of America 100, 15077-15082.

Yun, S.W., Ertmer, A., Flechsig, E., Gilch, S., Riederer, P., Gerlach, M., Schatzl, H.M., and Klein, M.A. (2007). The tyrosine kinase inhibitor imatinib mesylate delays prion neuroinvasion by inhibiting prion propagation in the periphery. J Neurovirol 13, 328-337. 


\section{Further Reading}

Caister Academic Press is a leading academic publisher of advanced texts in microbiology, molecular biology and medical research. Full details of all our publications at caister.com

- MALDI-TOF Mass Spectrometry in Microbiology Edited by: M Kostrzewa, S Schubert (2016) www.caister.com/malditof

- Aspergillus and Penicillium in the Post-genomic Era Edited by: RP Vries, IB Gelber, MR Andersen (2016) www.caister.com/aspergillus2

- The Bacteriocins: Current Knowledge and Future Prospects Edited by: RL Dorit, SM Roy, MA Riley (2016)

www.caister.com/bacteriocins

- Omics in Plant Disease Resistance Edited by: V Bhadauria (2016) www.caister.com/opd

- Acidophiles: Life in Extremely Acidic Environments Edited by: R Quatrini, DB Johnson (2016) www.caister.com/acidophiles

- Climate Change and Microbial Ecology: Current Research and Future Trend

Edited by: J Marxsen (2016)

www.caister.com/climate

- Biofilms in Bioremediation: Current Research and Emerging Technologies

Edited by: G Lear (2016)

www.caister.com/biorem

- Microalgae: Current Research and Applications Edited by: MN Tsaloglou (2016) www.caister.com/microalgae

- Gas Plasma Sterilization in Microbiology: Theory, Applications, Pitfalls and New Perspectives Edited by: H Shintani, A Sakudo (2016) www.caister.com/gasplasma

- Virus Evolution: Current Research and Future Directions Edited by: SC Weaver, M Denison, M Roossinck, et al. (2016) www.caister.com/virusevol

- Arboviruses: Molecular Biology, Evolution and Control Edited by: N Vasilakis, DJ Gubler (2016) www.caister.com/arbo

- Shigella: Molecular and Cellular Biology Edited by: WD Picking, WL Picking (2016) www.caister.com/shigella

-Aquatic Biofilms: Ecology, Water Quality and Wastewater Treatment

Edited by: AM Romaní, H Guasch, MD Balaguer (2016)

www.caister.com/aquaticbiofilms

- Alphaviruses: Current Biology

Edited by: S Mahalingam, L Herrero, B Herring (2016)

www.caister.com/alpha

- Thermophilic Microorganisms

Edited by: F Li (2015)

www.caister.com/thermophile
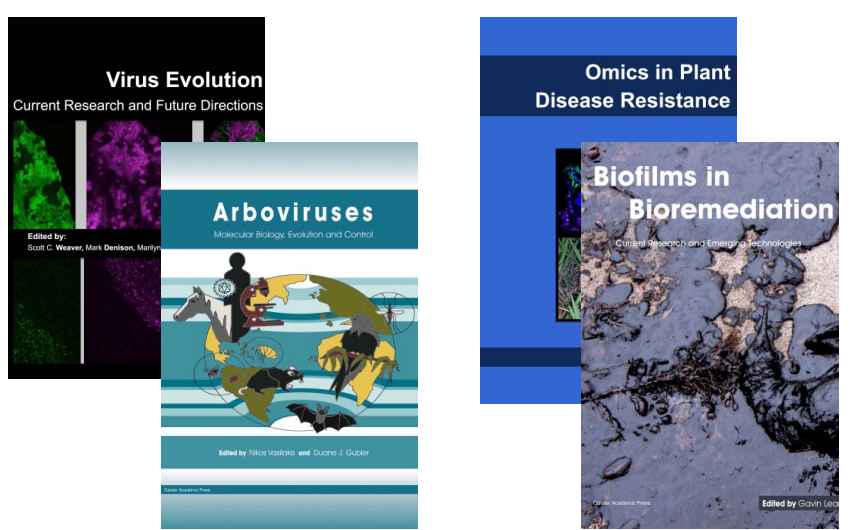
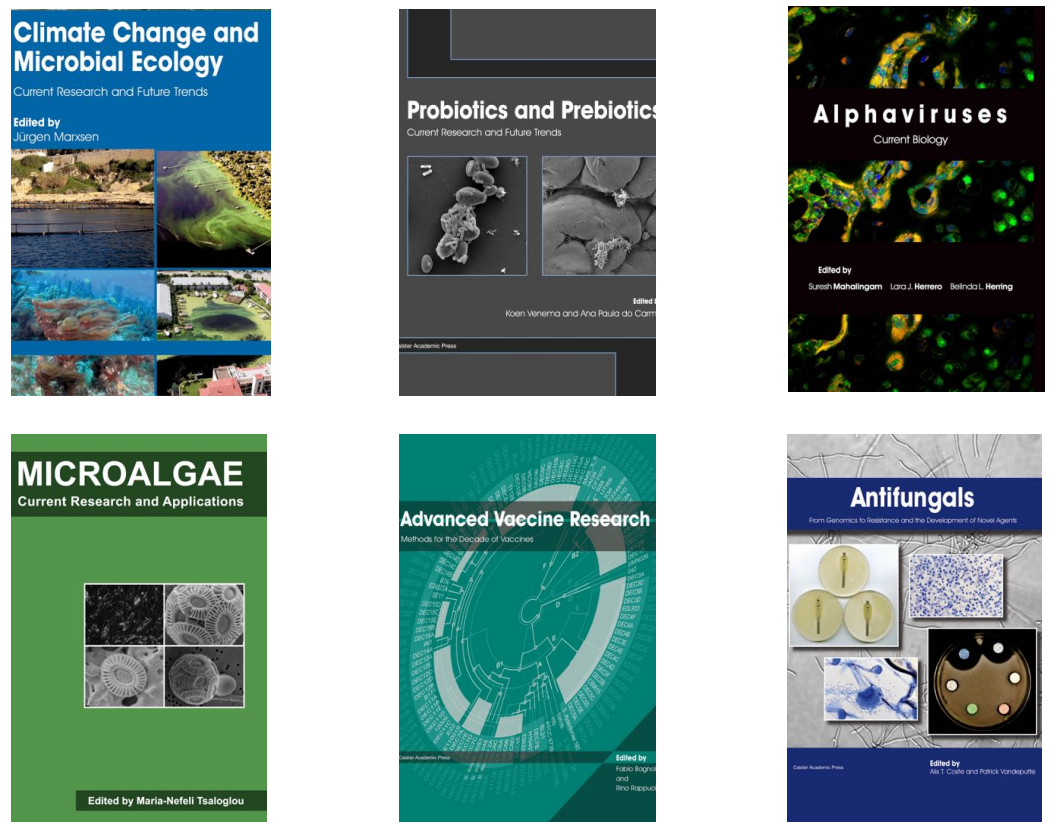

- Flow Cytometry in Microbiology: Technology and Applications Edited by: MG Wilkinson (2015) www.caister.com/flow

- Probiotics and Prebiotics: Current Research and Future Trends Edited by: K Venema, AP Carmo (2015) www.caister.com/probiotics

- Epigenetics: Current Research and Emerging Trends Edited by: BP Chadwick (2015) www.caister.com/epigenetics2015

- Corynebacterium glutamicum: From Systems Biology to Biotechnological Applications

Edited by: A Burkovski (2015)

www.caister.com/cory2

- Advanced Vaccine Research Methods for the Decade of Vaccines

Edited by: F Bagnoli, R Rappuoli (2015)

www.caister.com/vaccines

- Antifungals: From Genomics to Resistance and the Development of Novel Agents

Edited by: AT Coste, P Vandeputte (2015)

www.caister.com/antifungals

- Bacteria-Plant Interactions: Advanced Research and Future Trends Edited by: J Murillo, BA Vinatzer, RW Jackson, et al. (2015) www.caister.com/bacteria-plant

\section{- Aeromonas}

Edited by: J Graf (2015)

www.caister.com/aeromonas

- Antibiotics: Current Innovations and Future Trends

Edited by: S Sánchez, AL Demain (2015)

www.caister.com/antibiotics

- Leishmania: Current Biology and Contro Edited by: S Adak, R Datta (2015) www.caister.com/leish2

- Acanthamoeba: Biology and Pathogenesis (2nd edition) Author: NA Khan (2015)

www.caister.com/acanthamoeba2

- Microarrays: Current Technology, Innovations and Applications Edited by: Z He (2014)

www.caister.com/microarrays2

- Metagenomics of the Microbial Nitrogen Cycle: Theory, Methods and Applications

Edited by: D Marco (2014)

www.caister.com/n2 